\title{
The Digital Mindset as an Approach to Education forthe Millenial Generation
}

\author{
Sonny Eli Zaluchu \\ \{sonnyzaluchu@stbi.ac.id\} \\ Postgraduate Program, STBI Semarang
}

\begin{abstract}
Education in the millennium requires strategies and adjustments in the preparation and implementation of the teaching and learning process. The situation that surrounds the world of education also changes because of the strong influence of digitalization in all fields. Therefore, one of the educational strategies for the millennium is the need to develop digital narratives in the education process itself. Because the millennials rely heavily on digital technology, millennial education achieved through a pattern of technological determinism. An education system is a design in a teaching approach that adapts to learning styles and media technology so that it becomes more familiar and following the current culture. Digitizing the education system, as intended in Digital Narrative, will be in vain without a change in the mindset of all stakeholders in the education world. Therefore, in the millennial generation learning effort, the first step needed is to develop an educational system instrument, including learning strategies, which depart from the digital mindset. The next step is to integrate all these educational instruments into a technology-based education system. This article was prepared to discuss and criticize millennial education strategies with a digital narrative approach. The discussion was conducted qualitatively by referring to some theories and libraries.
\end{abstract}

Keywords: Education, Millenial Generation, Digital Mindset.

\section{Introduction}

The Millennial generation, also known as Generation $\mathrm{Y}$, is a term for the generation born in the period between 1980 and 2000. The main feature of this generation is the closeness and complete reliance on technology, particularly the internet. In his study on online unfocused debates by the millennial generation, Sabani concluded that unfocused debates are in fact symptomatic occurrences among in the millennial generation as a generational group that are inseparable from the use of the internet and social media[1]. The findings support the conclusion made by Taylor \& Keeter for Pew Research, who conducted an open survey among American adolescents, that dependence on technology is already part of the culture and life of adolescents in the category of the Y generation[2]. Furthermore, according to Valentine \& Powers, the military is considered a less religious but is the most educated and technologically literate generation[3]. Based on these findings, the millennial generation face the challenges of an era very different from the previous generation. In the area of education, for example, there is a challenge to make education as a place to prepare students for the types of work that have not been created before, especially in by using technology that has not been invented[4, p. 175]. The world is transformed into digital everything very quickly. Young people who study in this era are forced to adapt and actualize themselves quickly. Why? 
Technology is embedded in everything and the internet is the center of all life information (Internet of Things)[5, pp. 21-22]. Thus, rigid and conventional educational methods become irrelevant. The discourse on the presence of educational reforms, starting from the tools, curriculum, teaching methods and the learning process from start to end has become an inevitable demand. Such reality opens up vast opportunities and simultaneously presents a very serious challenge among educators and the world of education. Mukminan observes that there is a stronger connection between the world of science and technology in the 21st century. Such reality presents a demand for the world of education to be able to administer adequate governance. The aspiration to improve the quality of education must be in harmony with available technological developments[6]. Without such harmony, the educational endeavors to fulfill the demand for professional labor in the workforce will not be successful. A similar observation was made by Afandi who considered that a paradigm shift in the national education system is absolutely necessary to usher in the domain of Digital-Age Literacy. The goal is a pedagogical change, namely from traditional approach of simple action to technology-based comprehensive action[7]. What is the condition of education in Indonesia? This question has become the topic of discussion and research with the vested interest of reforming educational strategy in Indonesia in order to be relevant to development in the era, particularly in answering the needs of the millennial generation. The renewal of Indonesian education does not end at government regulation, but must be realized at the implementation level. This paper is an attempt to review the implementation directly related to the millennial generation education in order to be relevant to the rapidly changing world by raising the topic of Digital Mindset as the Millennial Generation Educational Approach.

\section{Method}

This paper is arranged by conducting document research, and library research. Documents are obtained from web showing about research reports on trends, the results of studies on behavior and phenomena among the millennial generation. Library research is carried out by tracing topics related to education and the generation $\mathrm{Y}$ phenomena in various journals and books. All data is processed and analyzed descriptively and systematically to answer the research objective. The writing and analysis process is guided by Positivism philosophy. This philosophical approach aims to explore social reality based on observation and reasoning [8, p. 77].

\section{Results and Discussion}

The analysis is prepared through a systematic process as follows. First, a description of the existential challenges of the millennial generation is described, proceeded by describing the main characteristics of the generation as the rationale, followed by a discussion of millennial education concepts and strategies, and closed with a conclusion.

\subsection{Existential Challenges of Millennials}

The sustainability of a generation is determined by how the generation prepares the next generation. The problem that often occurs in this transition is, as times change, there is a paradigm shift and the progress of the human way of life due to the influence of technology. 
Thus, the way each new generation actualizes itself within the era is different and contradicts the previous generation. The best example in describing this situation in the Bible is the success of Moses passing down his leadership to Joshua (wilderness generation) but the failure of the elders of Israel to pass on the spiritual values to the new generation of Israelites born in the promised land. Likewise with the success of David (first generation) handing over his reign to Solomon (second generation), and Solomon's failure to prepare the new generation through his children. The kingdom was divided in the third generation after David. The transition from post-World War baby boomers to generation X can be said to be smooth because baby boomers still have a direct role to nurture and raise generations of $\mathrm{X}$. Problems begin to occur at the turn of generation $\mathrm{X}$ (born between the 60s and 80s) towards generation $\mathrm{Y}$, which is called the millennial generation. As stated at the beginning, this millennial generation is nurtured by technology and all the fruit of development in the era, which did not exist before. Internet, high-tech and lifestyle, including internal values (inner values), have become part of the system and way of life. Thus, adaptation to old values, doctrines, traditions and various establishments that were once easily accepted by the $\mathrm{X}$ generation is rather questioned by Generation $\mathrm{Y}$ and is considered as an establishment that needs change.

Borrowing Derrida's approach to deconstruction, this generation can be said to have the tendency and courage to approach texts with new understanding previously unthinkable. Not recognizing the existence of absolute truth is one result $[9$, p. 238]. For example in the sociological domain, Moore's findings on the young generation of China, regarding shifts in values, from text of 'togetherness' to new phenomenal text, namely strong individualism[10]. The column written by Renzulli is interesting to look at, i.e. on how millennials view age. Baby boomers consider 73 year-olds as 'old' and generation $\mathrm{X}$ at age 65 . The millennial generation views old age at the age of 59. Whereas someone is said to be adult (ending adolescence) by according to the baby boomers generation and class $\mathrm{X}$ is at the age of 31 . The millenial generation extends the age group of youth to 40 years[11]. Likewise it is in problem solving. The way this generation resolves problems is different than the previous generation[12]. New techniques, theories and approaches have emerged in terms of problem solving that are more concise and straight to the point. All of these descriptions lead to one conclusion, that the millennial generation is not a phenomenal generation but the product of the times that must be appreciated and treated as the sign of the times that gave birth to it.

\subsection{Generations with Special Character}

A lot of effort has been made to study the nature and character of millennials that produces various researches and papers. All of these actions aim to find the right framing in repositioning the generation in various aspects of life. Through framing, wherever millennials are, a pattern of treatment can be formulated in order to maximize and efficate the generation. Regarding work ethics, for example, Gilbert's writing can be a reference[13]. For topics of lifestyle, the analysis of Amaro et al can be referred to[14]. Ashgar conducted research on how millennials practice entrepreneurship[15]. There are also studies of Meisser \& Willyerd on management strategies in mentoring millennials[16]. What about education?

Framing formulated from DeBard's research can be a reference for recognizing this group especially in terms of learning processes[17]. DeBard found seven millennial main characteristics, namely: (a) Special - this group identifies itself as a generation that has special characteristics in various segments; (b) Protected - This group exists because the system contributes to protection in protecting and guaranteeing the existence and survival through regulation; (c) Confidence - This group has strong self-confidence about a good future; (d) 
Conventional - This group is not easy to change, tends to hold strong beliefs in maintaining something that is considered good; (e) Team - This group shows dependency on the community and is more likely to be team-oriented and network strength; (f) Achievement This group has an objective attitude in evaluating things and making trends as achievements that must be followed / achieved; (g) Pressure - This group needs pressure and believes that compliance will be the key to achievement. One of DeBard's (philosophical) framing implementations can be seen in Prensky's (practical) view. According to him, preparing education for millennials must pay attention to the characteristics of the millennial group itself. In his study of nearly one thousand students from all economic, social, intellectual, and age background throughout the world, consistent facts were found regarding millennial characters. A number of these distinctive characters are millennial: (1) do not want to be lectured to; (b) want to be respected, trusted, and so that the opinion is valued and taken into account; (c) want to follow interests in this case self-interest; (d) want to make, use tools at work; (e) want to work in a group and project (and prevent slackers from getting a free ride); (f) want to make decisions and share control; (g) want to be connected in a network to express and share opinions, both in the class and in the world; (h) want to work together and compete with each other; and (i) want education that is not only relevant, but real. In summary, DeBard and Prensky, have paved the way by providing very important framing in formulating the approaches and practices of millennial education.

\subsection{Implementation of Culture and Digital Mindset}

As an effort to shape the education system and the millennial learning style, a new approach called Digital Narrative is needed. Prensky acknowledged that the millennial generation is very intense in their use of digital technology. According to him, this is not an obstacle but an opportunity. Millennial education can be achieved through a pattern of technological determinism. The education system is designed in a teaching approach that is adaptive to learning styles and media technology so that it becomes more familiar[18]. Digital Narrative is the process of digitizing the world of education, starting from the implementation to the provision of content, even the content itself. As postulated by the Greek philosopher Lucius Mestrius Plutarch (45-120 AD)[19], the mind is not a vessel that is ready to be filled up, but it is wood that needs to be ignited. Plutarch's statement concerns the need for a revolution in the paradigm of administering education. The shift has occurred due to technological advances and ways of dealing with education in the future, no longer depending on the patterns and understanding of education in the past. Digitizing the world of education is no longer a matter of 'filling up a bucket' but 'lighting a fire'. The most appropriate trigger of fire is technology as part of the culture of life of the millennial generation itself.

Kasali posited that the world (including the scope of education) was moving to find a new form that is more in line with the changing times. Technology has changed human interaction and all platforms adapt to information civilization. Thus the struggle is no longer a matter of product but platform. Strength is determined by data which turns into information and becomes input to knowledge[20, pp. 4-5]. The emergence of a digital education program called the Personalized Open Online Courses (POOC) has revolutionized the total face and scope of the education system. According to Naisbitt \& Naisbitt, POOC as an educational platform has facilitated the teaching and learning process without compromising the absence of inter-student interaction, and teacher / mentor-student interaction. The POOC is even able to become a link to student learning processes with the industrial world which is very beneficial for both parties, especially in the internship and placement program[4, pp. 204-7]. 
POOC is an example of a program for the digitalization of education by utilizing smart devices that millennials are very familiar with. Wherever a person may be, as long as she or he is connected to the internet, someone from any part of the world, without being limited by space and time, has social, cultural and geographical barriers, is able to learn and connect with others. All criteria proposed by Prensky, without noticed have been realized. Citing data released by the State of Connectivity Report 2015, Naisbitt \& Naisbitt said that at the end of 2015 , there were around 3.2 billion people already connected to the internet and using online platforms. What is more important is the conclusion formulated by the two futurologists, that smart phones and tablets have significantly helped students and teachers to have access to digital content, and are important tools in improving educational efforts[4, pp. 207-8].

Here are some implementations:

- The learning model and all the theories that support it have become obsolete and conservative. Although some didactic-methodic principles are still relevant, the world of education essentially requires a new theory based on technology and the application of digital methods into the education system itself. This is because education and all devices in it are facing a digital generation who are more familiar with tablets, books in the form of PDFs and online information, such as Google, Wikipedia, etc.

- The cause of misunderstanding when dealing with millennials is in giving wrong emphasis and approach. Many education systems (especially government regulations, educators and schools) attempt to answer the needs of the millennial generation by producing various digital education products (digitizing education). In fact, what is really needed is a digital mindset, much deeper than just a product. Because in the millennial generation digital life, this generation is not attached to the product but to the platform. Digital mindset is the platform.

- Changes and reforms in the direction of education need to be done boldly to answer the challenges of the times. The direction of education needs to be revised not only to educate the generation but to make the millennials capable of answering the challenges of the times and adjust to rapid changes. The real transformation of education will only occur if the education actor is treated not as a robot by the education system and curriculum, but as an integral part of the change towards a better life so that it has global competitive capabilities.

- What is needed in the implementation of Digital Narrative is the readiness of all education segments, starting from start to end. Government regulations have been formulated, seeming not yet optimal. Therefore all the practical tools of education must be plunged into the digital platform in all aspects of education, especially students and learning systems in schools. Stakeholders and education providers must immediately reform. Terms like 'anticipation' and 'this need time' are no longer excusable. Education in various parts of the world has changed towards a new platform. There are only two possibilities: change or survive for a while and then die.

\section{Conclusion}

Instrumentation and integration are the answers to efforts to revamp the millennial generation education system. This is because, changing the curriculum as has often been discussed, like training teachers to use the internet, installing free Wi-Fi in schools will never be beneficial without a digital mindset. Digital culture can only be produced from a digital mindset. Digitizing the education system, as intended in Digital Narrative, will be in vain 
without a change in the mindset of all stakeholders in the education world. Therefore, in the millennial generation educational effort, the first step needed is to develop an educational system instrument, including learning strategies, which depart from the digital mindset. The next step is to integrate all these educational instruments into a technology-based education system. It is not yet too late. However, thinking about it too long will cause Indonesian millennials to miss it forever.

\section{References}

[1] N. Sabani, "Generasi milenial dan absurditas debat kusir virtual," Informasi, vol. 48, no. 1, pp. 95-108, 2018.

[2] P. Taylor and S. Keeter, "Millennials: A Portrait of Generation next Confident, Connected and Open to Change," PewResearch Center, 2010. [Online]. Available: http://pewresearch.org/millennials/.

[3] D. B. Valentine and T. L. Powers, "Generation Y values and lifestyle segments," Journal of Consumer Marketing, 2013. [Online]. Available: http://pewresearch.org/millennials/.

[4] D. Naisbitt and J. Naisbitt, Mastering Megatrends - Menghadapi dan Menguasai Megatrends di Tatanan Global Baru. Jakarta: Bhuana Ilmu Populer, 2018.

[5] M. Frank, P. Reohrig, and B. Pring, Apa yang Harus Dilakukan Ketika Mesin Melakukan Semuanya. Jakarta: Elex Media Komputindo, 2018.

[6] Mukminan, “Tantangan Pendidikan di Abad 21," Semin. Nas. Teknol. Pendidik., 2014.

[7] Afandi, T. Junanto, and R. Afriani, "Implementasi Digital-Age Literacy dalam Pendidikan Abad 21 di Indonesia," in Prosiding Seminar Nasional Pendidikan Sains, 2016.

[8] J. Hartono, Ed., Filofosi dan Metodologi Penelitian, 1st ed. Yogyakarta: FEB UGM, 2017.

[9] Y. Z. Abidin, Filsafat Postmodern. Bandung: Pustaka Setia, 2018.

[10] R. L. Moore, "Generation ku: Individualism and China's millenial youth," Ethnology, vol. 44, no. 4, pp. 357-376, 2005.

[11] K. A. Renzulli, "This Is the Age When You Become 'Old,' According to Four Different Generations," time.com, 2017. [Online]. Available: http://time.com/money/4812751/this-is-theage-when-you-become-old-according-to-four-different-generations/.

[12] R. C. Giambatista, J. D. Hoover, and L. Tribble, "Millennials, Learning, and Development: Managing Complexity Avoidance and Narcissism," Psychol. J., 2017.

[13] J. Gilbert, "The Millennials: A new generation of employees, a new set of engagement policies," Ivey Bus. J., 2011.

[14] S. Amaro, L. Andreu, and S. Huang, "Millenials' intentions to book on Airbnb," Current Issues in Tourism, 2018.

[15] R. Asghar, "Study: Millenials are the True Entrepreneur Generation," Forbes, 2014. .

[16] J. C. Meiser and K. Willyerd, "Demografie - Mentoring Millenials," Harvard Bus. Manag., 2010.

[17] R. DeBard, "Millennials coming to college,” New Dir. Student Serv., 2004.

[18] C. Moore, "Teaching Digital Natives: Partnering for Real Learning," Int. J. Educ. Integr., vol. 6, no. 2, pp. 74-76, 2010.

[19] "Biography: Plutarch." [Online]. Available: https://www.biography.com/people/plutarch21338531.

[20] R. Kasali, The Great Shifting - Lebih Baik Pegang Kendali Daripada Dikuasai. Jakarta: PT. Gramedia Pustaka Utama, 2018. 